Original research article

\title{
Attachment of vulnerable adolescents in residential facilities in the Czech Republic
}

\author{
Pavla Doležalová ${ }^{1 *}$, Karel Červenka ${ }^{2}$, Věra Vojtová ${ }^{2}$ \\ ${ }^{1}$ National Institute of Mental Health, Klecany, Czech Republic \\ ${ }^{2}$ Masaryk University, Faculty of Education, Department of Special and Inclusive Education, Brno, Czech Republic
}

\begin{abstract}
We are presenting some of the results of a study that examined the prevalence of attachment styles among children with emotional behavioral disorders (EBD) from special educational residential facilities in the Czech Republic. The development of EBD that brought these children into residential facilities was influenced by a variety of factors. One of such risk factors can be an attachment disorder influencing behavior, socialization and resilience.

The aim of the research was to determine the prevalence of attachment style, anxiety and avoidance of vulnerable adolescents towards father and mother as possible determinants of behavioral disorders.

The research group consisted of 204 respondents aged 15-19 years. The respondents were clients from 15 residential facilities from all over the Czech Republic.

We used the ECR-RS self-assessment questionnaire containing 36 items to determine attachment to emotional targets (mother/ father). We processed the data using descriptive statistical procedures using the ANOVA or Spearman coefficient procedure.

Findings regarding attachment indicate a high degree of avoidance and anxiety in vulnerable adolescents. In most respondents, an insecure attachment is prevalent. The most represented is preoccupied attachment to the mother in $36 \%$. Only $14 \%$ of the examined adolescents formed a secure attachment to the mother.

Complex intervention and psychotherapy should focus on alleviating anxiety and avoidance, developing a secure attachment, and enhancing the resilient qualities of vulnerable adolescents.
\end{abstract}

Keywords: Anxiety; Attachment style; Avoidance; Prevalence, Vulnerable adolescents

\section{Introduction}

In this article, we focus on the attachment of adolescents who have spent a portion of their lives in residential educational facilities. These are young people who have been court-ordered to have an institutional or protective education imposed. These are children whose life path has been burdened by a number of risk factors from the social environment in which they live. In our research,we sought to answer the question to what extent the disruption of attachment contributes to the situation of young people in educational institutions.

The residential facilities of special education programs are a form of intervention support for individuals with emotional and behavioral disorders. It represents a significant intervention in the child's life and is imposed in a situation where outpatient or boarding form of intervention does not work or is ineffective. The intervention must be individualized and responsive to the specific needs of the individual. Questions of a child's behavioral and relationship with other people are usually characterized by negative attunement. In this context, Kobak et al. (2017) describe a parenting practice of individual sensitive attunement to build self-confidence, autonomous decision-making, and communication skills. Futhermore, sensitive attunement and secure attachment are mechanisms to reduce risky behavior and support the development of resilience (Doležalová, 2018). If the child lacks the opportunity to establish a secure attachment with members of his/ her primary group (usually parents), the fulfillment of some of the developmental preconditions and thus also the basic needs is endangered. The child cannot openly experience life situations, thus blocking or limiting his/her further personal development and increasing the risk of vulnerability factors (Zeanach and Gleason, 2015). In this context, attachment is an important factor influencing the child's level of resilience and vulnerability, not only in childhood, but also adulthood.

The style of attachment, and the dimension of avoidance and anxiety in attachment are reflected in many areas of the child's life: in their behavior, experience and ability to develop interpersonal relationships. Vulnerable adolescents are more

\footnotetext{
* Corresponding author: Pavla Doležalová, National Institute of Mental Health, Topolová 748, 25067 Klecany, Czech Republic; e-mail: pdolezalova1@gmail.com http://doi.org/10.32725/kont.2021.042

Submitted: 2020-05-04 • Accepted: 2020-09-02 • Prepublished online: 2020-09-24 
likely to be avoidant or anxious due to high-risk environment, early neglect, loss or trauma, compared to adolescents who grew up in a safe environment (Mellick et al., 2019; Read et al., 2018). On the contrary, a secure relationship in early childhood can be perceived as a protective factor which is positively reflected in resilience, the ability to regulate behavior and experience, and in establishing high-quality sustainable relationships.

The collection of data took place via a questionnaire survey in several selected educational institutions. The main tool of the questionnaire survey was the ECR-RS questionnaire (Fraley et al., 2011).

The aim was to analyze the prevalence of attachment in girls and boys to the mother and father, as well as the dimensions of avoidance and anxiety as determinants of potential influence on manifestations in the behavior of these young people.

In the text below, we will first present the theoretical basis of the research. We will briefly introduce the issue of attachment in adolescents characterized by high vulnerability and risky behavior. Research on attachment in this group is particularly warranted, as this group is rarely included in research studies.

\section{Attachment in childhood}

The impact of attachment in childhood and early interaction with people have a profound effect on the future functioning of the individual in society - and consequently on their mental health. It can be said that early childhood experience has an impact on resilience and many aspects of the quality of the following stages of his/her life (Citak and Erten, 2021; Langmeier and Matějček, 2011).

The initial research of attachment in childhood was carried out by Bowlby (2010), who described attachment as a range of emotional and cognitive representation created and strengthened from the first months of the child's life. Many authors have followed up on his findings. In childhood, it is a dyadic relationship in the early stages of life that forms the basis for a proper relationship with oneself or others. This also has an impact on self-esteem, mental health and wellbeing (Greger et al., 2017; Suzuki and Tomoda, 2015). Al-Yagon (2016) states that it is generally accepted that children form an attachment style not only in the dyadic child-mother connection, but also in other close relationships. However, it is not clear which relationships have the greatest influence on the subsequent development of the child.

Furthermore, Keren and Mayseless (2013) mention that subsequent relationships may be secure even if the original dyadic attachment in childhood was insecure. The stability of relationships in the early stages of childhood and family ties supports characteristic and significant experiences of forming security and trust, as well as resilience throughout life (Waters et al., 2000). If there is abuse, neglect, failure of care by parents or other wardens, these experiences can negatively affect the child's ability to regulate its emotions, impulsivity and behavior. Adverse stimuli in childhood have a negative effect on the development of empathy and positive social skills or on authentic personality identity (Taylor et al., 2013). This state of vulnerability is a breeding ground for psychological and psychosomatic disorders. Dissociative processes based on early attachment trauma are also activated (Doležalová, 2018).

\section{Attachment styles}

The modern theory of attachment is dealt with by experts from different perspectives, so there are several variants of how to describe the styles of attachment. For our purposes, we present attachment styles using a four-category model (Gunlicks-Stoessel et al., 2019): (1) secure attachment style; (2) anxious-preoccupied attachment style; (3) dismissive-avoidant attachment style; (4) fearful-avoidant attachment style.

Secure attachment style

Secure attachment style is characterized by stability, higher resilience, lower levels of stress, trust in oneself and others, and feeling comfortable in relationships. Individuals with a secure attachment have sufficient self-confidence, self-esteem, self-trust and a sufficient degree of integrity and self-control. Young people with a secure attachment trust other people, are inquisitive, perceive the meaning and importance of their studies, and fulfill short-term and long-term goals towards autonomy in adulthood. Roughly $6 \%$ of girls in institutional programs have experienced a secure attachment to their parents. This is in contrast to the general population of young people, where secure attachment prevalence varies from about $25 \%$ to 60\% (Doležalová, 2018; Lečbych and Pospíšilíková, 2012).

Dismissive-avoidant attachment style

In contrast to the previous style, the dismissive-avoidant attachment style is characterized by a significant distancing, avoidance and coldness in intimate relationships. However, an individual with this attachment style maintains a positive image of him or herself, especially in the sense that he/she emphasizes his/her independence and own strength. Young people who have a dismissive style tend to refuse to ask a teacher or therapist for help and devalue relationships with adults (Doležalová, 2018).

\section{Preoccupied attachment style}

Preoccupied attachment style is characterized primarily by ambivalence. These young people have a negative attitude towards themselves while preserving a positive image of others. They long for a relationship, especially with their peers, as it can improve their perception of their self-image. Some young people compensate for their unfulfilled need for childhood love through relationships with older partners or use drugs to alleviate their emotional pain (Doležalová, 2018).

Fearful-avoidant attachment style

The fearful-avoidant attachment style is characterized by a negative image of oneself and others. It manifests itself in unpredictability, fear of rejection and emotional hurt. Young people with this attachment trust neither others nor themselves, having often experienced traumatic events in early childhood or not having had an opportunity to meet their parents for many reasons and having grown up in an institutional setting (Doležalová, 2018).

\section{Materials and methods}

\section{Objectives}

As explained above, a certain type of attachment is related to risk factors in mental health. This particular type of attachment may therefore carry complex risk consequences during adulthood. The following questions arise:

What is the prevalence of attachment styles among adolescents in residential facilities?

What type of attachment is closer to the dimension of anxiety and avoidance regarding important attachment targets in the observed adolescents? 
This pilot research is unique due to its focus. A systematic collection of data on vulnerable adolescents who are in residential facilities of special education programs for children with risky behavior has never been systematically carried out by the founder of these institutions (Ministry of Education, Youth and Sports of the Czech Republic). In the last few years, however, there have been pilot research studies in the field of mental health (Dolejšová, 2017; Doležalová, 2018).

Our research involved adolescents who have spent several years in residential facilities due to a number of accumulated adverse life circumstances. Based on a court decision, these adolescents are accepted into residency programs in special education programs. These decisions are most often related to a variety of risks, the violation of legal norms, truancy or drug use, or in connection with a neglected and risky family environment.

The aim of the research was to map the prevalence of attachment in vulnerable adolescents to the mother and father, and to determine their anxiety and avoidance as possible determinants of behavioral risks.

The research took place in 2019. The research field consisted of residential educational institutions from several regions.

The research group was designed in two steps. First, residential facilities were selected and approached. In the next step, the clients present at that time were approached as potential respondents. Vulnerable adolescents could also be identified in mainstream education, but in residential programs, potential respondents are clearly formally identifiable on the basis of a court decision on a mandatory institutional education or on imposing protective education.

The facilities were selected with regard to several factors. Given the sensitive nature of the topic being studied - which is closely linked to issues of trust and security - we tried to ensure the safest possible situation for the data collection i.e., from the respondents' point of view, the situation in which they filled in the questionnaires. We therefore selected 15 residential educational facilities. In addition, the main selection criterion was that these were facilities with which researchers had cooperated before. This aspect was crucial, as residential educational facilities with limited access can be considered as quasi-total institutions. For successful data collection, we needed access to the facility and, equally important, for their staff to trust the members of our research team. One of the essential selective factors was the respondents' willingness to participate in our research. Participation in the research was voluntary and the respondents were allowed to refuse to participate without providing reasons. They were also allowed to refuse to answer any of the questions and/or express disagreement with the processing of certain data or information. This possibility was emphasized in the informed consent form which the respondents received.

The participating respondents received and signed information about the research project - and their roles in the research were explained to them. They were also acquainted with the rights associated with their participation in the project and also with the methods of data handling (anonymization). All of this occurred through informed consent.Prior to the actual collection of data, the consent of the management of the relevant school facility was also obtained. Furthermore, the date of implementation and the conditions of data collection were chosen upon agreement.

\section{Characteristics of the sample}

The sample consisted of 204 respondents, female and male, aged 15-19, who were in residential educational programs. At that time, the respondents were clients of one of the 15 residential facilities from within the network of such facilities from all over the Czech Republic (which consists of a total of 25 facilities). The research sample was made up of more girls ( $N=121$ girls) than boys ( $N=83$ boys), as girls were willing to cooperate in this research more often than boys. Boys were less accessible during data collection.

In this context, it is useful to provide some brief information on the target group. In the school year 2018/19, a total of 933 young people of both genders (348 girls, 585 boys) stayed in residential facilities in the Czech Republic. Our research group numbered 204 respondents, which is approximately $1 / 5$ of the target population of young people in residential facilities in the period.

\section{Research tool and data analysis}

The ECR-RS questionnaire (Fraley et al., 2011) was used in the section of our project from which we are drawing data for this study. The ECR-RS self-assessment questionnaire consists of 36 items that allow the researchers to reveal the nature of emotionally intimate relationships.. The respondent fills in the items separately for each target person. Items are rated on a seven-point Likert scale ( $1=$ strongly disagree, $7=$ strongly agree). There are six items related to the avoidance dimension and three items related to the anxiety dimension.

We came to our findings through quantitative analysis of the collected data, using statistical procedures. We included statistical descriptive analysis of data with a variation of statistical procedures using ANOVA or Spearman's coefficient. Furthermore, statistical analyses of the occurrence of individual types of attachment of the observed adolescents to close persons were performed, including anxiety and avoidance.

\section{Results}

The results of the study summarize the distribution of anxiety, avoidance and the prevalence of attachment styles of adolescents to mother and father. We analyzed and examined the domains of anxiety and avoidance related to mother and father and the prevalence of individual attachment styles as possible determinants of the behavior of adolescent girls and boys at risk of behavioral issues.

\section{Anxiety and avoidance related to mother and father}

In the following table, we present the anxiety and avoidance related to the mother and father. The analysis of these indicators is followed by an analysis and division of the monitored adolescents into four types of attachment. The overall anxiety/ avoidance rate was summarized as the arithmetic mean of all four attachment styles.

The determined results of the rate of avoidance and anxiety are presented in Table 1 . There is a higher rate of father avoidance than mother avoidance, both for girls and boys (average score 4.29). On the contrary, there is lower rate of avoidance in relation to the mother (average score 3.89). Boys and girls have a higher degree of anxiety towards their mother (average score 3.61) than towards their father. The mother is an essential primary relational figure in early childhood. The loss or threat of abandonment by the mother are common among adolescents in residential facilities. Uncertainty towards the mother can increase anxiety in both boys and girls. 
Table 1. Anxiety and avoidance - Adolescents in residential facilities

\begin{tabular}{|c|c|c|c|c|c|c|}
\hline Mother/Father & Minimum & Maximum & Mean & $\begin{array}{l}\text { Standard } \\
\text { deviation }\end{array}$ & Median & $\begin{array}{l}\text { Number of } \\
\text { responses }(N)\end{array}$ \\
\hline \multicolumn{7}{|l|}{ Avoidance domain } \\
\hline Mother & 1.00 & 7.00 & 3.89 & 1.68 & 4.00 & 165 \\
\hline Father & 1.00 & 7.00 & 4.29 & 1.61 & 4.60 & 156 \\
\hline \multicolumn{7}{|l|}{ Anxiety domain } \\
\hline Mother & 1.00 & 7.00 & 3.61 & 1.91 & 3.67 & 165 \\
\hline Father & 1.00 & 7.00 & 3.26 & 1.96 & 3.00 & 156 \\
\hline
\end{tabular}

The domain of avoidance and anxiety is an indicator of stress. High levels of anxiety have the effect of suppressing one's needs, and the inability to talk about what an individual needs from himself or others. Anxiety leads to withdrawal into one's inner self, negative expectations of oneself and low self-esteem. Anxiety in adolescence can be masked by unstable mood, such as outbursts of anger and hatred towards others and parents. Similarly to anxiety, individuals with a high rate of avoidance also hide their emotional needs with imbalance. Adolescents with a high rate of avoidance believe they cannot even expect the fulfillment of their needs, they perceive others negatively and do not trust others to meet their needs. Avoidant individuals tend to saturate their needs in adolescence by superficial surrogate or virtual non-binding and short-term relationships.

The evaluation of the results indicates anxiety or avoidance towards the individual person. The psychometric properties of ECR-RS acquire high values of Cronbach's alpha reliability from 0.85 to 0.92 (Fraley et al., 2011). The measurement of relationship structure in adolescents showed high validity (Feddern Donbaek and Elklit, 2014). Similar psychometric results were confirmed in the $C$ zech version of the questionnaire (Lečbych and Pospíšilíková, 2012).

\section{Analysis of the prevalence of individual attachment styles in relation to the mother and father}

For the analysis of individual attachment style, emotionally close targets were chosen, using the methodology of the ECR-RS questionnaire (Fraley et al., 2011). We focused on analyzing the attachment styles to the mother and father. With regard to the theory of attachment and the purpose of this research study, we chose mother/father because of their emotional significance. We examined the prevalence of individual attachment among adolescents to both parents.

Table 2 shows the distribution of the types of attachment to the mother. No statistical differences were found between boys and girls. The most represented is preoccupied attachment to the mother in $36 \%$. Only $14 \%$ of the examined adolescents formed a secure attachment to the mother.
Table 2. Distribution of attachment styles to the mother

\begin{tabular}{lrr} 
Mother (attachment style) & $N$ & $\%$ \\
\hline Mother is absent & 18 & 9.8 \\
Secure & 26 & 14.2 \\
Avoiding & 7 & 3.8 \\
Preoccupied & 66 & 36.1 \\
Anxious preoccupied & 66 & 36.1 \\
Total & 183 & 100.0 \\
\hline
\end{tabular}

Table 3 shows the differences in the representation of attachment styles between girls and boys. These results show a relatively higher proportion of preoccupied attachment to the father in girls compared to boys. Furthermore, girls have a relatively higher proportion of fearfully-avoiding attachment to the father compared to boys. Differences which verge on statistical significance are already apparent $(0.05<p<0.1)$. Secure attachment to the father is the least represented in girls (5\%), while it is slightly higher for boys (8\%). It should be noted that one third of these adolescents has no connection with the father. $14 \%$ of girls and boys have a secure connection to their mother. Less than $7 \%$ of boys and girls have a secure connection to their father.

\section{Discussion}

Secure attachment plays a key role in creating resilience. It also contributes to the interpersonal and intrapersonal aspects of personality development in adolescent girls and boys in institutional behavioral modification programs. Our findings show high avoidance and anxiety among vulnerable adolescents. A low representation of a secure attachment to parents occurs similarly among girls and boys. The respondents are on the contrary more likely to have a preoccupied or fearful attachment to their parents.

Table 3. Distribution of attachment styles among girls and boys to the father

\begin{tabular}{|c|c|c|c|c|c|c|c|}
\hline & & \multicolumn{5}{|c|}{ Father (attachment style) } & \multirow[b]{2}{*}{ Total } \\
\hline & & Absent father & Secure & $\begin{array}{l}\text { Rejective- } \\
\text { avoiding }\end{array}$ & Preoccupied & $\begin{array}{l}\text { Fearfully- } \\
\text { avoiding }\end{array}$ & \\
\hline \multirow{4}{*}{ Gender } & \multirow{2}{*}{ Girls } & 12 & 4 & 2 & 47 & 14 & 79 \\
\hline & & $15.2 \%$ & $5.1 \%$ & $2.5 \%$ & $59.5 \%$ & $17.7 \%$ & $100.0 \%$ \\
\hline & \multirow{2}{*}{ Boys } & 21 & 9 & 5 & 43 & 32 & 110 \\
\hline & & $19.1 \%$ & $8.2 \%$ & $4.5 \%$ & $39.1 \%$ & $29.1 \%$ & $100.0 \%$ \\
\hline \multirow{2}{*}{ Total } & & 33 & 13 & 7 & 90 & 46 & 189 \\
\hline & & $17.5 \%$ & $6.9 \%$ & $3.7 \%$ & $47.6 \%$ & $24.3 \%$ & $100.0 \%$ \\
\hline
\end{tabular}


In most boys and girls, an insecure attachment prevails; in particular the preoccupied and fearfully-avoiding attachment styles are present. The differences in the representation of the types of attachment between boys and girls are the same for the mother, and no statistical differences were found between the sexes. The most represented is the fearfully-avoiding and preoccupied attachment to the mother (which occurs in 36\%). Only $14 \%$ of both genders form a secure attachment to the mother. Security and safety as protective factors are formed primarily in interpersonal relationships built from childhood. Strengthening protective factors and the quality of interpersonal relationships are essential in both childhood and adolescence, where it is possible to shape personality.

Due to the uncertainty, avoidance and distrust of the participating young people, it is necessary to build long-term trust and strengthen resilient characteristics in the form of special educational and psychosocial therapeutic interventions. Resilient characteristics include, for example, tolerance to stress and its negative effects, and healthy testing of potentially risky situations (Moreno et al., 2016). Individuals with a secure attachment, high self-confidence and self-worth, and positive prosocial and flexible behavior in a given social reality have the aforementioned and other abilities (Al-Yagon, 2016).

Studies confirm a higher degree of security in adolescents placed in residential facilities who have been in early contact with their biological parents during their residential program (Kobak et al., 2017). Anxiety in adolescents is also affected by a number of adverse circumstances faced by the family as a result of the separation phase between the children and the parents. Active communication with parents during the transitional phase towards independence and the possibility of returning back home had high benefits for adolescents.

The limitations of the study were the amount of missing data for mother or father related questions in the ECR-SR questionnaire. Due to traumatic early childhood experiences, some adolescents refused to answer certain questions. The most common missing data were the loss of a parent in terms of lack of interest and neglect by the biological parent, placement in early institutional care until the age of 5 or not knowing the biological parents at all..Adolescents responded by not filling in the questions because they were upset. Five adolescents refused to fill in a part of the questionnaire and discontinued the interview after questions about their mothers and early trauma and neglect.

Furthermore, the selection of respondents was voluntary within selected institutions of institutional behavioral modification. These were only respondents who voluntarily agreed to participate in the research survey. More data were obtained from facilities for girls, because girls were more willing to fill out questionnaires and work with researchers than boys. Boys were more likely to refuse to participate in the research at all. There was a degree of avoidance and distrust of the researcher or a lack of interest in responding to all of the questions about their relationship with their parents. Alternatively, fatigue after schooling and lack of interest in filling out the questionnaires might have played a role as well. The fact that these adolescents are impulsive and display ADHD symptoms, or have developed huge psychiatric comorbidity due to early trauma or neglect might have also been significant in our data collection. The studied adolescents did not have intellectual disabilities.

The collection of data took an hour, and this time was also a limit, as adolescents did not have the patience to fill out a longer questionnaire and came tired from school. Also, the data collection was not rewarded by incentives, everything was based on their motivation and voluntary cooperation.

\section{Conclusions}

The findings support the comprehensive direction of special education and psychotherapeutic interventions in developing secure relationships. They also support the strengthening of resilient characteristics in therapeutic and behavioral modification programs. A better understanding of the attachment in girls and boys to other close persons, as well as the dimensions of avoidance and anxiety, can improve emotional and social aspects of these vulnerable adolescents. Our findings suggest strengthening the well-being of vulnerable adolescents and creating a secure professional atmosphere. This study provides novel evidence for future research into attachment in vulnerable adolescents in residential facilities.

\section{Ethical aspects and conflict of interests}

The authors have no conflict of interests to declare.

\section{Funding}

The project was supported within the grant procedure of the Ministry of Education, Youth and Sports for the year 2019. No. PRCH-IP-0095/2019 (Primary prevention of risky behavior for the year 2019). The beneficiary and implementer of the project is Masaryk University. The project was implemented in cooperation with the National Institute of Mental Health, Klecany - this study is the result of research activities supported by the project number LO1611 with the financial support of the Ministry of Education, Youth and Sports within the NPUI program. 


\section{Citová vazba vulnerabilních adolescentů v institucionálních zařízeních v České republice}

\section{Souhrn}

Prezentujeme část výsledků z výzkumné studie, která zkoumala prevalenci citové vazby u dětí s poruchami chování a emocí (PCHE) ze speciálněpedagogických programů v institucionálních zařízeních v České republice. Rozvoj poruch chování a emocí souvisí s řadou faktorů, které měly vliv na umístění dětí do programů institucionálních zařízení. Jedním z takových rizikových faktorů může být porucha citové vazby, která má vliv na chování, socializaci a resilienci.

Cílem výzkumu bylo zjistit prevalenci stylu citové vazby k otci a matce, míru úzkostnosti a vyhýbavosti u vulnerabilních adolescentů jako možných př́ícin poruch chování a emocí.

Výzkumnou skupinu tvořilo 204 respondentů ve věku 15-19 let. Respondenty byli klienti z 15 pobytových zařízení z celé České republiky.

Ke zjištění citové vazby k emocionálním osobám (matka/otec) jsme použili sebehodnoticí dotazník Experiences in Close Relationships (ECR-RS) obsahující 36 položek. Data jsme zpracovali pomocí deskriptivních statistických postupů s použitím procedury ANOVA nebo Spearmanova koeficientu.

Výsledky této studie týkající se citové vazby naznačují vysokou míru vyhýbavosti a úzkostnosti u vulnerabilních adolescentů $\mathrm{k}$ matce a otci. U většiny respondentů převládá nejistá citová vazba k rodičům. Nejvíce zastoupena byla zapletená citová vazba k matce v 36 \%. Pouze 14 \% vulnerabilních adolescentů mělo vytvořenou jistou citovou vazbu k matce.

Komplexní intervence a psychoterapie je třeba zaměřit na zmírnění úzkostnosti a vyhýbavosti. Zejména rozvíjet jistou citovou vazbu a posilovat resilientní charakteristiky u vulnerabilních adolescentů.

Klíčová slova: prevalence; styl citové vazby; úzkostnost; vulnerabilní adolescenti; vyhýbavost

\section{References}

1. Al-Yagon M (2016). Perceived Close Relationships With Parents, Teachers, and Peers: Predictors of Social, Emotional, and Behavioral Features in Adolescents With LD or Comorbid LD and ADHD. J Learn Disabil 49(6): 597-615. DOI: $10.1177 / 0022219415620569$.

2. Bowlby J (2010). Vazba - Teorie kvality raných vztahů mezi matkou a dítětem, Praha: Portál. From original: Attachment and loss-Attachment, London, the Tavistock institute of Human Relations, 1969.

3. Citak C, Erten E (2021). Impact of Childhood Trauma and Attachment on Resilience in Remitted Patients with Bipolar Disorder. J Affect Disord 280(Pt A): 219-227. DOI: 10.1016/j. jad.2020.11.025.

4. Dolejšová A (2017). Osobnostní rysy rizikového chování v souvislosti s typy citové vazby a fenomén užívání tabáku u adolescentek ve výchovných ústavech v České republice. Diplomová práce. Klinika adiktologie 1. LF UK a VFN, Praha.

5. Doležalová P (2018). Relationship between Attachment and Aspects of Mental Health of Adolescent Girls in Institutional Educational Care. PhD. Theses, Pedagogická fakulta, Univerzita Karlova, Praha.

6. Feddern Donbaek D, Elklit A (2014). A validation of the Experiences in Close Relationships-Relationship Structures scale (ECR-RS) in adolescents. Attach Hum Dev 16(1): 58-76. DOI: 10.1080/14616734.2013.850103.

7. Fraley RC, Heffernan ME, Vicary AM, Brumbaugh CC (2011). The experiences in close relationships - Relationship Structures Questionnaire: A method for assessing attachment orientations across relationships. Psychol Assess 23(3): 615-625. DOI: $10.1037 / \mathrm{a} 0022898$.

8. Greger HK, Myhre AK, Klöckner CA, Jozefiak T (2017) Childhood maltreatment, psychopathology and well-being: The mediator role of global self-esteem, attachment difficulties and substance use. Child Abuse Negl 70: 122-133. DOI: 10.1016/j. chiabu.2017.06.012.

9. Gunlicks-Stoessel M, Westervelt A, Reigstad K, Mufson L, Lee $S$ (2019). The role of attachment style in interpersonal psychotherapy for depressed adolescents. Psychother Res 29(1): 78-85. DOI: 10.1080/10503307.2017.1315465.
10. Keren E, Mayseless O (2013). The freedom to choose secure attachment relationships in adulthood. J Genet Psychol 174(3): 271-290. DOI: 10.1080/00221325.2012.681326.

11. Kobak R, Abbott C, Zisk A, Bounoua N (2017). Adapting to the changing needs of adolescents: parenting practices and challenges to sensitive attunement. Curr Opin Psychol 15: 137-142. DOI: 10.1016/j.copsyc.2017.02.018.

12. Langmeier J, Matějček $Z$ (2011). Psychická deprivace v dětství. 4th suppl. ed. Praha: Karolinum, p. 399.

13. Lečbych M, Pospíšilíková K (2012). Česká verze škály, Experiences in Close Relations (ECR): Pilotní studie posouzení vztahové vazby v dospělosti, E-Psychologie, ČMPS 6(3): 1-11.

14. Mellick WH, Mills JA, Kroska EB, Calarge CA, Sharp C, Dindo LN (2019). Experiential Avoidance Predicts Persistence of Major Depressive Disorder and Generalized Anxiety Disorder in Late Adolescence. J Clin Psychiatry 80(6): 18m12265. DOI: $10.4088 / J C P .18 \mathrm{~m} 12265$.

15. Moreno C, García-Moya I, Rivera F, Ramos P (2016). Characterization of Vulnerable and Resilient Spanish Adolescents in Their Developmental Contexts. Front Psychol 7: 983. DOI: 10.3389/fpsyg.2016.00983.

16. Read DL, Clark GI, Rock AJ, Coventry WL (2018). Adult attachment and social anxiety: The mediating role of emotion regulation strategies. PloS One 13(12): e0207514. DOI: 10.1371/journal.pone.0207514.

17. Suzuki H, Tomoda A (2015). Roles of attachment and selfesteem: impact of early life stress on depressive symptoms among Japanese institutionalized children. BMC Psychiatry 15(1): 8. DOI: 10.1186/s12888-015-0385-1.

18. Taylor ZE, Eisenberg N, Spinrad TL, Eggum ND, Sulik MJ (2013). The relations of ego-resiliency and emotion socialization to the development of empathy and prosocial behavior across early childhood. Emotion 13(5): 822-831. DOI: 10.1037/ a0032894.

19. Waters E, Hamilton CE, Weinfield NS (2000). The stability of attachment security from infancy to adolescence and early adulthood: general introduction. Child Dev 71(3): 678-683. DOI: 10.1111/1467-8624.00175.

20. Zeanah CH, Gleason MM (2015). Annual research review: Attachment disorders in early childhood - clinical presentation, causes, correlates, and treatment. J Child Psychol Psychiatry 56(3): 207-222. DOI: 10.1111/jcpp.12347. 